\title{
Aerosol analysis using a Thermal-Desorption Proton-Transfer-Reaction Mass Spectrometer (TD-PTR-MS): a new approach to study processing of organic aerosols
}

\author{
R. Holzinger ${ }^{1}$, J. Williams ${ }^{2}$, F. Herrmann ${ }^{2}$, J. Lelieveld ${ }^{2}$, N. M. Donahue ${ }^{3}$, and T. Röckmann ${ }^{1}$ \\ ${ }^{1}$ Institute for Marine and Atmospheric research Utrecht, Princetonplein 5, 3584 CC, Utrecht, The Netherlands \\ ${ }^{2}$ Max Planck Institute for Chemistry, Mainz, Germany \\ ${ }^{3}$ Center for Atmospheric Particle Studies, Carnegie Mellon University, Pittsburgh PA 15213, USA
}

Received: 25 November 2009 - Published in Atmos. Chem. Phys. Discuss.: 3 December 2009

Revised: 5 February 2010 - Accepted: 5 February 2010 - Published: 3 March 2010

\begin{abstract}
We present a novel analytical approach to measure the chemical composition of organic aerosol. The new instrument combines proton-transfer-reaction mass-spectrometry (PTR-MS) with a collection-thermal-desorption aerosol sampling technique. For secondary organic aerosol produced from the reaction of ozone with isoprenoids in a laboratory reactor, the TD-PTR-MS instrument detected typically $80 \%$ of the mass that was measured with a scanning mobility particle sizer (SMPS). The first field deployment of the instrument was the EUCAARI-IOP campaign at the CESAR tall tower site in the Netherlands. For masses with low background values ( $\sim 30 \%$ of all masses) the detection limit of aerosol compounds was below $0.2 \mathrm{ng} / \mathrm{m}^{3}$ which corresponds to a sampled compound mass of $35 \mathrm{pg}$. Comparison of thermograms from ambient samples and from chamber-derived secondary organic aerosol shows that, in general, organic compounds from ambient aerosol samples desorb at much higher temperatures than chamber samples. This suggests that chamber aerosol is not a good surrogate for ambient aerosol and therefore caution is advised when extrapolating results from chamber experiments to ambient conditions.
\end{abstract}

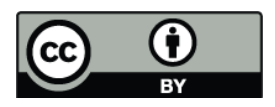

Correspondence to: R. Holzinger (r.holzinger@uu.nl)

\section{Introduction}

Organic aerosol (OA) sources in the global atmosphere are enormously uncertain. While state-of-the-art models predict total organic aerosol formation rates of $12-70 \mathrm{Tg} \mathrm{yr}^{-1}$ (Hallquist et al., 2009; Kanakidou et al., 2005), alternative budgeting approaches indicate significantly higher OA production. Field observations consistently reveal 3-10 times more organic aerosol than predicted by models (Heald et al., 2005; Volkamer et al., 2006), while top-down estimates suggest between 60 and $330 \mathrm{TgC} \mathrm{yr}^{-1}$ (120-660 $\left.\mathrm{Tg} \mathrm{OA} \mathrm{yr}^{-1}\right)$ (Goldstein and Galbally, 2007), again several times higher than global model predictions. The search for this "missing" source of OA has become a key research topic, with hypotheses including higher secondary organic aerosol (SOA) yields from volatile organic precursors such as isoprene (Kroll et al., 2006; Paulot et al., 2009) or toluene (Hildebrandt et al., 2009; $\mathrm{Ng}$ et al., 2007), heterogeneous uptake of glyoxal (Kroll et al., 2005; Volkamer et al., 2007), aqueous photochemistry (Ervens et al., 2008), or oxidation of low vaporpressure "intermediate volatility organics" (IVOC) (Donahue et al., 2006; Grieshop et al., 2008; Robinson et al., 2007).

Not only is there more organic aerosol in the atmosphere than represented by models, it is also oxidized to a very high degree. A compilation of aerosol mass spectrometer (AMS) field observations in the northern hemisphere shows that approximately $95 \%$ of the OA mass in the remote continental boundary layer has a characteristic electron-impact ionization mass spectrum dubbed "oxidized organic aerosol" (OOA), with urban environments containing about $67 \%$ OOA (Zhang et al., 2007). Subsequent principal component analyses have decomposed ambient AMS data into four to

Published by Copernicus Publications on behalf of the European Geosciences Union. 
six factors, typically including two classes of OOA (Lanz et al., 2008), and the advent of high-resolution time-of-flight AMS measurements (DeCarlo et al., 2006) has enabled more accurate determination of the oxygen content of those factors (Aiken et al., 2008). The oxygen-to-carbon ratio (O:C) of the OOA ranges from about 0.5:1 for the less oxygenated OOA-2 to about 1:1 for the more heavily oxygenated OOA-1 (Aiken et al., 2008). Field observations employing a temperaturescanning thermodenuder reveal that OOA-1 is relatively less volatile while OOA-2 is relatively more volatile (Huffman et al., 2009), consistent with observed correlations between OOA- 1 and sulfate, and between OOA- 2 and nitrate (Lanz et al., 2008). Accordingly these two groups are now referred to as semi-volatile OOA (SV-OOA) and low volatility OOA (LV-OOA), respectively (Jimenez et al., 2009). Even if the absolute values of O:C and volatility from these measurements remain uncertain, they show conclusively that a substantial fraction of the OA has been subject to oxidation processes..

Here we described a new analytical approach, ThermalDesorption Proton-Transfer-Reaction Mass Spectrometry (TD-PTR-MS), based on a novel combination of an aerosol inlet previously developed for in situ thermal desorption GCMS (Williams et al., 2006) and proton-transfer reaction mass spectrometry (PTR-MS, Holzinger et al., 2007) to evaluate both the composition and volatility of organic aerosol. The conceptual idea is similar to the method described by Thornberry et al. (2009). The TD-PTR-MS instrument fills a niche because it allows for aerosol measurements at a time resolution below 1 hour, with detailed and comprehensive physicochemical information and an excellent detection limit. Therefore the new instrument has a high potential to elucidate chemical processes that transform fresh aerosol (either primary emissions or first-generation secondary aerosol observed in smog-chamber experiments) to the highly oxidized aerosol that is typically observed in the field.

We report first results obtained from chamber produced secondary organic aerosol (SOA) from ozonolysis of isoprenoids and from ambient aerosol as measured during the EUCAARI-IOP campaign in Cabauw, Netherlands, in May 2008.

\section{Experimental}

\subsection{The TD-PTR-MS instrument}

The TD-PTR-MS instrument consists of a modified commercial PTR-MS (Ionicon Inc., Innsbruck, Austria) which is equipped with both a gas and an aerosol inlet. A full description of PTR-MS and its functionality is given elsewhere (Lindinger et al., 1998; Hansel et al., 1995). Here, we briefly describe the aspects that are necessary to understand the potential of the new approach: PTR-MS is a chemical ionization technique using protonated water $\left(\mathrm{H}_{3} \mathrm{O}^{+}\right)$as ionizing agent. Guided by an electrical field of $\sim 60-70 \mathrm{~V} / \mathrm{cm}$, the $\mathrm{H}_{3} \mathrm{O}^{+}$ions are pulled through the drift tube in which a typical pressure of $2-4$ mbar is maintained by a low flow (10$15 \mathrm{~mL} / \mathrm{min}$ ) of sample gas. A small fraction of primary ions reacts with organic species in the sample gas. The amount of product ions formed in the drift tube is directly proportional to the concentration of the organic compounds in the sample gas. Primary ions and product ions are detected with a mass spectrometer. The data reported here rely on a unit mass resolution quadrupole mass spectrometer, but we are in the process up upgrading to a high mass resolution time-offlight mass spectrometer.

The use of PTR-MS as detector for aerosol compounds is highly advantageous for the following reasons: (i) PTR-MS is a relatively soft ionization technique; many compounds do not fragment and are detected at their protonated mass (molecular weight +1$)$. If fragmentation occurs it often follows a well-defined pattern such as the loss of an $\mathrm{H}_{2} \mathrm{O}$ fragment in the case of higher alcohols. (ii) PTR-MS is very sensitive and therefore low detection limits in aerosol analysis can be achieved. (iii) Virtually all compounds constituting the "organic carbon" fraction in aerosols can be detected, and (iv) although compounds are only identified by their mass to charge ratio in the mass spectrometer they can still be quantified at the $\sim 30 \%$ accuracy level because of the well-defined conditions in the drift tube and the fact that proton-transfer reaction rates are usually close to the ion-molecule collision rate when a reaction is energetically possible.

The centerpiece of the aerosol inlet is a CollectionThermal-Desorption (CTD) cell (Aerosol Dynamics, Berkeley, CA, USA) that is similar in design to the CTD cell used with the Thermal Desorption Aerosol Gas Chromatograph described by (Williams et al., 2006). The CTD cell collects ambient particles in the $0.07-2 \mu \mathrm{m}$ size range at an air sample flow rate of $1 \mathrm{~L} / \mathrm{min}$, and allows for gradual thermal desorption of the collected sample into the PTR-MS system. Particle collection is done by humidification-aided impaction, whereby the ambient airstream is humidified to $\sim 70 \% \mathrm{RH}$ by a Nafion-based humidifier to reduce particle rebound, and then impacted onto the stainless steel collection surface using a sonic jet impactor. Additionally, the CTD cell contains an auxiliary injection port for the manual introduction of liquid standards by means of a syringe. All parts in contact with volatilized aerosol compounds (i.e. the CTD cell, the PTRMS drift tube, and all transfer tubing and valves) were coated to increase the chemical inertness of the surface. The CTD cell coating is AMCX (AMCX, L.L.C., Lemont PA, USA); all other parts received the "Restek Sulfinert" treatment. The transfer lines and the PTR-MS drift tube were operated at elevated temperatures of $200^{\circ} \mathrm{C}$ to avoid re-condensation of evaporated aerosol compounds.

A schematic drawing of the instrument is presented in Fig. 1. In the "load" mode, air is pulled through the CTD cell via valves 2 and 3, and the aerosols are collected on a sharp point in the CTD cell. While loading the CTD cell, 
the PTR-MS is connected via valve 1 to the gas phase inlet. In principle, the PTR-MS performs conventional gas phase measurements in this mode. However, due to the high operating temperature of the drift tube and inlet lines a significant fraction of the aerosols evaporates, so that in fact we detect the combined signal of gas phase and condensed-phase organics rather than gas phase mixing ratios alone.

For the aerosol analysis, valves 2 and 3 are closed and valve 1 is switched to the aerosol inlet. A small flow of 10 $12 \mathrm{~mL} / \mathrm{min}$ of nitrogen carrier gas transports all compounds evaporating from the CTD cell directly into the PTR-MS. Note that there is no further splitting of the flow so that $100 \%$ of the CTD cell effluent passes through the drift tube of the PTR-MS. The temperature of the CTD cell is ramped at a rate of $25^{\circ} \mathrm{C} / \mathrm{min}$ from ambient temperatures $\left(\sim 25^{\circ} \mathrm{C}\right)$ to a maximum temperature of $350^{\circ} \mathrm{C}$. Thus an aerosol measurement can be completed in about $15 \mathrm{~min}$. Compounds that are volatilized at CTD cell temperatures above $200^{\circ} \mathrm{C}$ may recondense on the cooler transfer lines. This may lead to contamination and a substantial loss of the low-volatility fraction. So far we have not observed significant effects of recondensation, however, the particular characteristics of this potential problem still need to be thoroughly investigated.

The PTR-MS measures mixing ratios of aerosol-derived compounds in the nitrogen carrier gas. The mass concentration of an aerosol compound in the air sample can be calculated according to

$n_{\text {aer }, x}=\left(C_{\text {mean }, x} \times \mathrm{MW}_{x} \times F_{N 2} \times t_{\text {meas }}\right) /\left(22.4 \times F_{\text {col }} \times t_{\text {col }} \times 0.001\right)$, (1)

where $n_{\text {aer }, x}$ is the aerosol concentration of compound $X$ in $\mathrm{ng} \mathrm{m}^{-3}, C_{\text {mean }, x}$ its (arithmetic) mean mixing ratio during the aerosol analysis in the nitrogen carrier gas in $\mathrm{nmol} / \mathrm{mol}$, $\mathrm{MW}_{x}$ the molecular weight of compound $X$ in $\mathrm{g} / \mathrm{mol}, F_{N 2}$ the flow of the carrier gas in standard liters per minute, $t_{\text {meas }}$ the duration of the aerosol measurement in minutes, $F_{\mathrm{col}}$ the flow rate at which the aerosols are collected in standard liters per minute, and $t_{\mathrm{col}}$ the duration of aerosol collection in minutes. The CTD cell represents a preconcentration step because the aerosols of a gas volume $F_{\mathrm{col}} \times t_{\mathrm{col}}$ are transferred into the much smaller volume $F_{N 2} \times t_{\text {meas }}$. For equal collection and analysis times the preconcentration is a factor of $F_{\mathrm{col}} / F_{N 2} \sim 100$, with longer sampling times preconcentration factors of 1000 can be easily achieved. The preconcentration step is an important feature because it enables detection of many individual compounds in aerosols, even in very clean ambient air samples. Other approaches that use chemical ionization techniques (including PTR-MS) for aerosol analysis are, thus far, either restricted to chamber experiments (Hellen et al., 2008; Hearn and Smith, 2004), or to compounds with a relatively high volatility (Thornberry et al., 2009).

After a cool down period of 10-15 min a new collection cycle can be started. Valve switching, heating/cooling etc. is automated and therefore the system is capable of continuous measurements over extended periods of time.

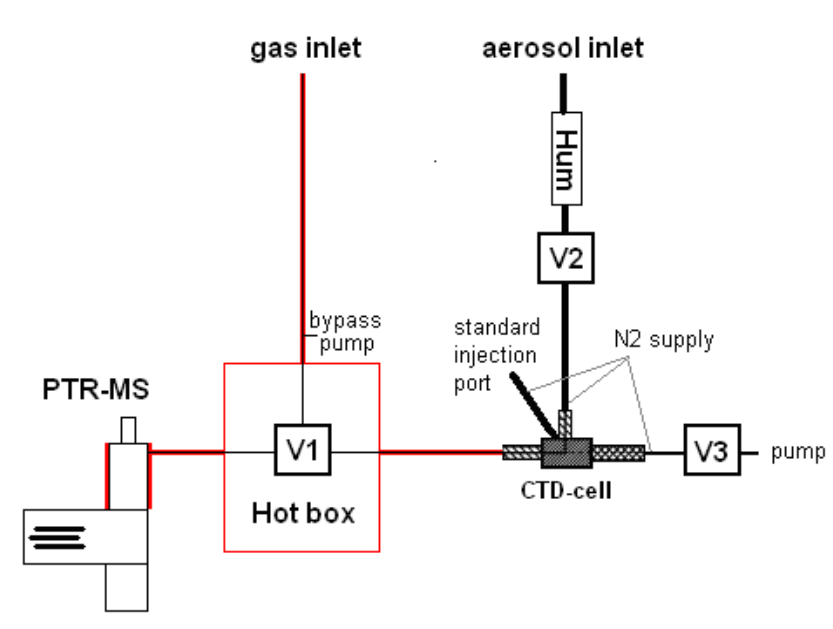

Fig. 1. Schematic drawing of the setup. Areas marked in red were operated at high temperatures of $200^{\circ} \mathrm{C}$.

\subsection{Quantification of uncalibrated aerosol compounds}

Ambient organic aerosols often contain hundreds of different compounds and it is not possible to calibrate the instrument with standard mixtures for each of the constituents. Therefore we rely on calculation of the mixing ratio according to

$C_{x}=\left(S_{x} / t r_{x}\right) /\left[\left(S_{19} \times k_{19} / t r_{19}+S_{37} \times k_{37} / t r_{37}\right) \times t_{\text {react }} \times N\right]$,

where $C_{x}$ is the volume mixing ratio of compound $X$ in units of $\mathrm{mol} / \mathrm{mol} ; S_{x}, S_{19}$, and $S_{37}$ are the ion signals of compound $X, \mathrm{H}_{3} \mathrm{O}^{+}$, and the protonated water dimer, $\left(\mathrm{H}_{2} \mathrm{O}\right)_{2} \mathrm{H}^{+}$, in counts per second; $t r_{x}, t r_{19}$, and $t r_{37}$ are the respective dimensionless transmission factors of the quuadrupole mass spectrometer; $k_{19}$ and $k_{37}$ are the reaction rate constants of compound $X$ with $\mathrm{H}_{3} \mathrm{O}^{+}$and $\left(\mathrm{H}_{2} \mathrm{O}\right)_{2} \mathrm{H}^{+}$, respectively, in units of $\mathrm{cm}^{3} \mathrm{~s}^{-1}$ molecule ${ }^{-1} ; t_{\text {react }}$ the residence time of $\mathrm{H}_{3} \mathrm{O}^{+}$ions in the drift tube; and $\mathrm{N}$ the number density of the sample gas in the drift tube in molecules per $\mathrm{cm}^{3}$.

The number density $\mathrm{N}$ is calculated according to

$N=N_{0} \times p_{\text {drift }} \times T_{0} /\left(p_{0} \times T_{\text {drift }}\right)$,

where $N_{0}$ is $2.69 \times 10^{19}$ molecules $\mathrm{cm}^{-3}$ at $273 \mathrm{~K}\left(T_{0}\right)$ and $1013.25 \mathrm{hPa}\left(p_{0}\right) ; p_{\text {drift }}$ and $T_{\text {drift }}$ are the pressure and temperature in the drift tube, respectively. The residence or reaction time of $\mathrm{H}_{3} \mathrm{O}^{+}$ions in the drift tube is calculated according to $t_{\text {react }}=d / v_{d}$, where $d=9.6 \mathrm{~cm}$, the length of the drift tube, and $v_{d}$, the drift velocity of the hydronium ions is calculated according to

$v_{d}=E \times \mu_{0} \times p_{0} \times T_{\text {drift }} /\left(p_{\text {drift }} \times T_{0}\right)$,

where $E$ is the electrical field in $\mathrm{V}$ per $\mathrm{cm} ; \mu_{0}=2.7 \mathrm{~cm}^{2} / \mathrm{Vs}$, the reduced mobility of $\mathrm{H}_{3} \mathrm{O}^{+}$in nitrogen $\left(\mathrm{N}_{2}\right)$, and the other values as in Eq. (3). Since the abundance of the protonated 


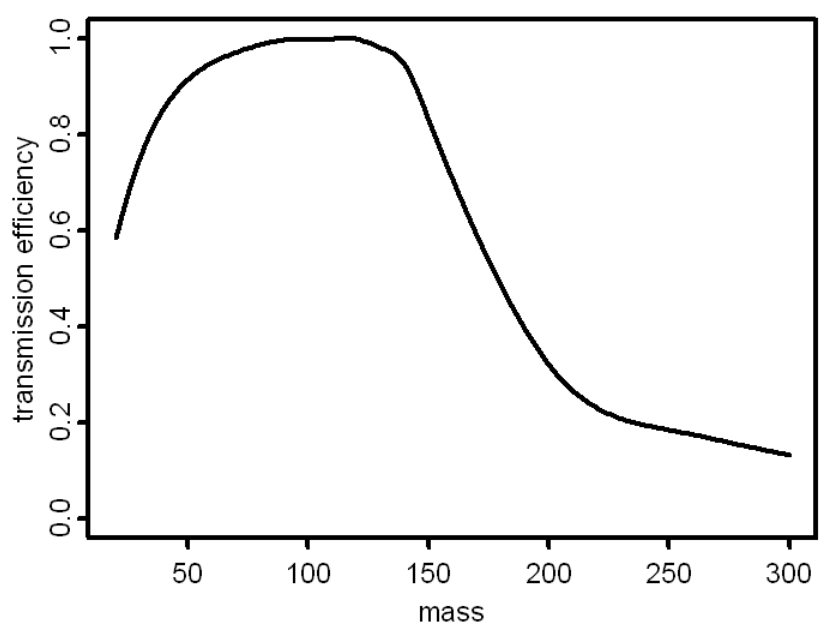

Fig. 2. Fractional transmission efficiency of the PTR-MS quadrupole mass spectrometer.

water dimer can be up to $20 \%$ of the $\mathrm{H}_{3} \mathrm{O}^{+}$signal, the protonated water dimer is considered as second primary ion in Eq. (2).

The transmission efficiency of the quadrupole mass spectrometer was regularly measured by sequentially measuring standard mixtures (mixing ratios of several $\mu \mathrm{mol} / \mathrm{mol}$ ) of a set of calibration compounds for a few seconds. The transmission efficiency with respect to the primary ion signal can be calculated from the relative decrease/increase of the primary/product ion, respectively. For example, trimethylbenzene has been used to calibrate the transmission efficiency at mass 121 . When an increase of one million counts per second was observed at mass 121 the corresponding decrease of the primary ion signal was typically only 550000 counts per second. For $\mathrm{m} / \mathrm{z}$ ratios above $121 \mathrm{Da}$, no appropriate calibration substances were available and we used the known fragmentation pattern of $\beta$-caryophyllene (Demarcke et al., 2009 ) to optimize our transmission curve. Above an $m / z$ ratio of 205 the transmission efficiency was estimated. Figure 2 shows the transmission curve that was used for calculating mixing ratios.

For the majority of organic compounds the reaction rate constant is in the range $1.7-2.5 \times 10^{-9} \mathrm{~cm}^{3} \mathrm{~s}^{-1}$ molecule ${ }^{-1}$ (Zhao and Zhang, 2004). However, oxygenated compounds can react at higher rates of up to $3.8 \times 10^{-9} \mathrm{~cm}^{3} \mathrm{~s}^{-1}$ molecule ${ }^{-1}$, and values above $4 \times 10^{-9} \mathrm{~cm}^{3} \mathrm{~s}^{-1}$ molecule ${ }^{-1}$ are reported for some compounds. In this work we use a standard reaction rate constant of $2 \times 10^{-9} \mathrm{~cm}^{3} \mathrm{~s}^{-1}$ molecule ${ }^{-1}$.

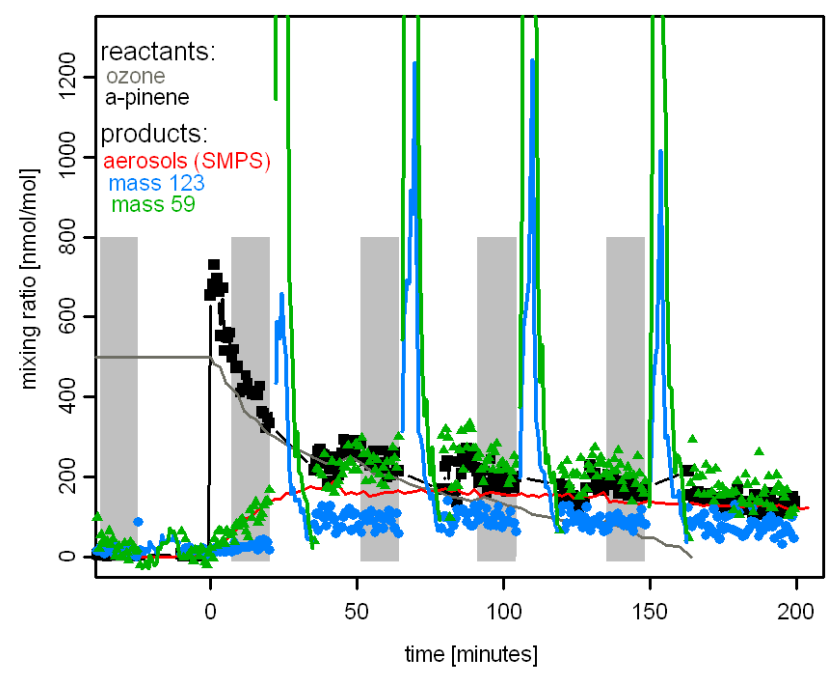

Fig. 3. Development of gas phase and aerosol species during an ozonolysis experiment. The grey shaded areas indicate the $15 \mathrm{~min}$ time periods of aerosol sampling. At time $t=0$ the monoterpene was added and the reaction immediately started as can be seen by decreasing mixing ratios of ozone (grey) and $\alpha$-pinene (black). SMPS data are in units of $\mu \mathrm{g} \mathrm{m}^{-3}$. The units for aerosol compounds (green/ blue solid lines) refer to mixing ratio of the evaporated aerosol compound in the N2 carrier gas; gas phase compounds (symbols) refer to mixing ratios in the smog chamber. See text for further explanation.

\section{First Results and discussion}

\subsection{Smog chamber measurements}

Smog-chamber experiments were performed in an evacuable 570 liter volume spherical glass vessel at the Max Planck Institute for Chemistry in Mainz. The experiments we report here were performed in the period 22-29 October 2008. We analyzed SOA from the ozonolysis of isoprene, $\alpha$-pinene, limonene, and $\beta$-caryophyllene. Ozone and gas-phase compounds were monitored with FTIR and TD-PTR-MS, respectively. Aerosol concentrations were measured with an SMPS instrument and with TD-PTR-MS. During the smog-chamber experiments the TD-PTR-MS recorded full mass spectra in the mass range $20-419 \mathrm{Da}$ at a scanning speed of $0.1 \mathrm{~s}$ per mass unit, so that a full mass scan was completed in $40 \mathrm{~s}$.

A typical course of an ozonolysis experiment is shown in Fig. 3. Before the start of the experiment the vessel was pressurised ( $\sim 980 \mathrm{hPa}$ ) with humidified air; ozone was added at typical levels of several $100 \mathrm{~s} \mathrm{nmol} / \mathrm{mol}$. The experiment was started by injecting the reactant $(\sim 700 \mathrm{nmol} / \mathrm{mol}$ of $\alpha$-pinene for the experiment shown in Fig. 3). The reaction immediately started, as can be seen by decreasing mixing ratios of ozone and $\alpha$-pinene. Figure 3 also depicts the course of the mixing ratio of two products detected at masses 59 and $123 \mathrm{Da}$ in the TD-PTR-MS. The symbols in Fig. 3 denote gas-phase mixing ratios; maximum mixing ratios of $\sim 250$ 

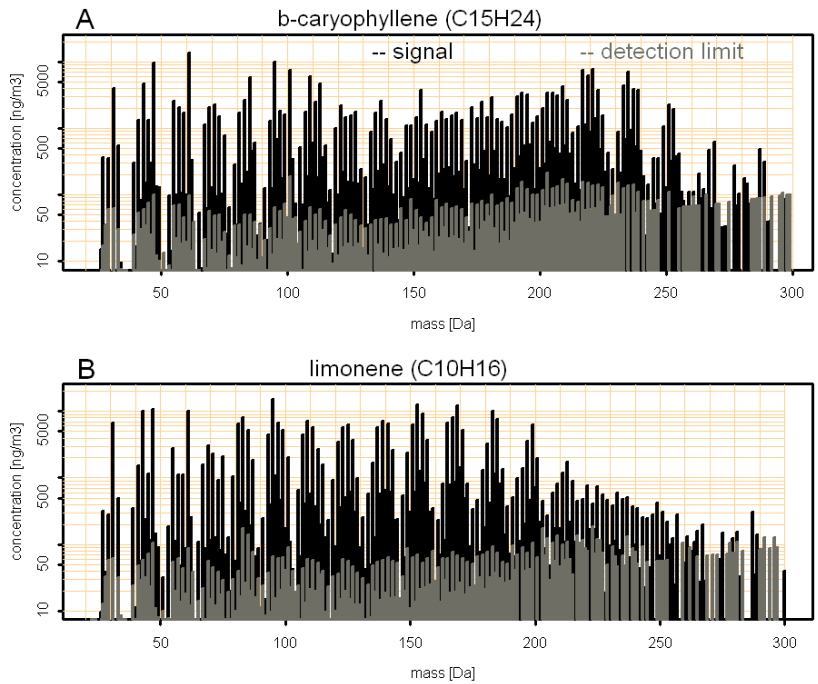

Fig. 4. Two examples of compounds constituting chamber aerosol that was produced from (a) b-caryophyllene and (b) limonene ozonolysis.

and $\sim 75 \mathrm{nmol} / \mathrm{mol}$ indicate molar gas phase yields of $35 \%$ and $10 \%$ for $\mathrm{m} 59$ and $\mathrm{m} 123$, respectively. The maximum particle concentration was reached 40-75 min after the start of the experiment. The grey shaded areas in Fig. 3 indicate the 15-min time periods of aerosol sampling. The aerosols were immediately analysed after collection and therefore the green and blue lines in Fig. 3 represent the abundance of compounds in aerosols detected at mass 59 and 123, respectively. Due to the preconcentration on the CTD cell the mixing ratio is much higher during the aerosol measurement even though the concentration of the detected compounds is much larger in the gas phase.

\subsubsection{Detected masses}

Figure 4 shows mass concentrations of compounds that were measured in aerosol produced from ozonolysis of $\beta$ caryophyllene $\left(\mathrm{C}_{15} \mathrm{H}_{24}\right)$ and limonene $\left(\mathrm{C}_{10} \mathrm{H}_{16}\right)$. The concentrations were corrected for background contamination on the individual masses. On most masses the signal was significantly above the detection limit (also shown in Fig. 4), which was calculated as 3 times the standard error of the background signal. The protonated masses of $\beta$-caryophyllene and limonene are 205 and $137 \mathrm{Da}$, respectively, and they both have 2 double bonds that can react with ozone. Thus, a total of 4 oxygen atoms can be added by straightforward ozone chemistry and the highest masses that are therefore expected in the mass spectra are 269 and 201 for $\beta$-caryophyllene and limonene, respectively. Masses above these threshold values contribute very little to the burden of total aerosol mass (Fig. 4). It is remarkable that high signals were observed at low molecular weights. The most prominent low-mass-peaks were detected at $31,43,47$, and $61 \mathrm{Da}$. The detected signal
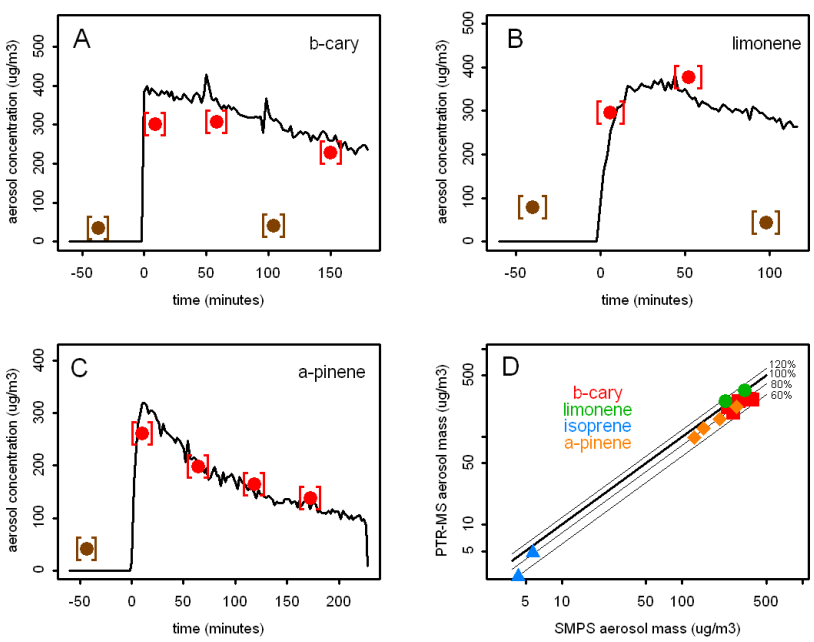

Fig. 5. Evolution of aerosol mass during ozonolysis of bcaryophyllene, limonene, and a-pinene (a-c). Black lines represent the aerosol concentration as measured with the SMPS, TD-PTRMS data are plotted as red circles (background measurements are plotted in brown). The brackets indicate the period during which aerosols have been sampled. Panel (d) shows a scatter plot of aerosol mass measured with the SMPS and TD-PTR-MS respectively. The aerosol mass measured with TD-PTR-MS was typically $20 \%$ below the values obtained with the SMPS. See text for interpretation.

at mass 48 and 62 was $1.5 \pm 0.3 \%$ and $2.5 \pm 0.3 \%$ of the signal detected at mass 47 and 61 , respectively. We conclude that the ions detected at mass 47 and 61 contain 1 and 2 carbon atoms, respectively. Therefore masses 31,47 , and 61 can be attributed to protonated formaldehyde, formic acid and acetic acid, respectively. At room temperature these compounds have high saturation vapour pressures $(>150 \mathrm{hPa})$ and their contribution to the aerosol phase should be negligible. Therefore, the signals we observe at low molecular weights must be fragments of heavier compounds and the low masses may actually be associated with high molecular weight compounds. Such thermal decomposition products have been observed in several other studies (e.g. Tobias and Ziemann, 2000; Cappa et al., 2008).

\subsubsection{Mass balance}

The total aerosol mass measured with the TD-PTR-MS system was calculated by summing up the contributions from all individual ions. Figure $5 \mathrm{a}-\mathrm{c}$ shows the evolution of aerosol mass during ozonolysis of $\beta$-caryophyllene, limonene, and $\alpha$-pinene as obtained with the TD-PTR-MS system and the SMPS. The TD-PTR-MS system of course has a lower temporal resolution when compared to SMPS, but it captures the general evolution well. The TD-PTR-MS has some background signal which results in above zero concentrations at times when no aerosols were present in the chamber 

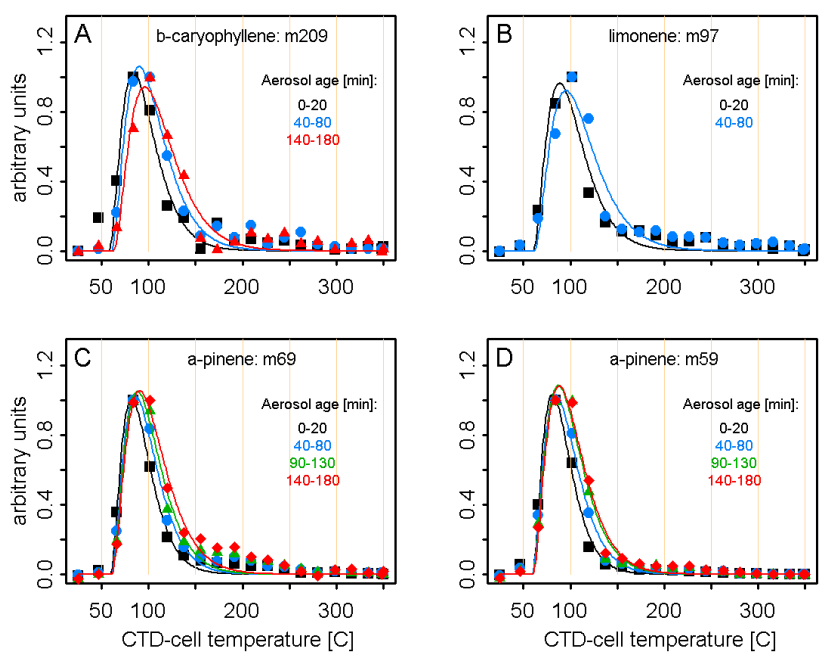

Fig. 6. Typical thermograms of organic compounds from secondary organic aerosol produced from ozone and terpenes. The individual thermograms are normalized. With increasing aerosol age the aerosol compounds evaporate at slightly higher temperatures.

(negative times in Fig. 5). Occasionally we also measured the background signal after the start of the ozonolysis experiment by loading the CTD cell through a filter (Balston, Model 9922-05) that removed the aerosols. Two of these background measurements can be seen in Fig. $5 \mathrm{a}$ and $\mathrm{b}$ at times around $100 \mathrm{~min}$. The TD-PTR-MS total aerosol mass data shown in Fig. $5 \mathrm{~d}$ have been corrected by subtracting the appropriate background data. A scatter plot of total aerosol mass measured with the SMPS (assuming density $1 \mathrm{~g} \mathrm{~cm}^{-3}$ ) versus the total aerosol mass measured with the TD-PTR-MS system (Fig. 5d) shows that the total aerosol mass measured with the TD-PTR-MS was typically $20 \%$ below the mass measured with the SMPS. It is actually expected that the TDPTR-MS measures a lower total aerosol mass because, as discussed above, a significant fraction of aerosol compounds fragment during the protonation process. When fractionation occurs during a proton-transfer reaction only one fragment can be detected in the mass spectrometer, i.e. the fragment that carries the charge. The neutral fragment(s) are not detected and therefore a certain fraction of the aerosol mass is lost and cannot be accounted for. We can roughly estimate the lost fraction by attributing signals below $90 \mathrm{Da}$ to fragments and the signals above $90 \mathrm{Da}$ to protonated compounds. In a second step we calculate the average molecular weight from the "protonated compounds". For the two measurements shown in Fig. 4 these are $162 \mathrm{Da}$ and $141 \mathrm{Da}$ for $\beta$-caryophyllene and limonene, respectively. In a third step we use the average molecular weight to calculate the individual contributions from masses below $90 \mathrm{Da}$ according to Eq. (1). Applying this simple procedure we find that $66-76 \%$ of the total aerosol mass should be detected. If we run the same procedure but using 60 and $120 \mathrm{Da}$ as thresh- old that separates fragments from protonated compounds, we compute that $80-85 \%$ and $57-68 \%$ of the total aerosol mass is detected. Whereas a threshold of $60 \mathrm{Da}$ is certainly too low, $120 \mathrm{Da}$ is probably on the high end of potentially reasonable threshold values. Therefore we conservatively state that the TD-PTR-MS instrument detected $55-80 \%$ of the total aerosol mass. The better agreement in Fig. 5d is probably an indication that the average reaction rate constant for proton transfer reactions of the $\mathrm{H}_{3} \mathrm{O}^{+}$ions with aerosol compounds is larger than the value of $210^{-9} \mathrm{~cm}^{3} \mathrm{~s}^{-1}$ molecule $^{-1}$ that we used for calculating the concentrations.

\subsubsection{Information obtained from the thermograms}

The controlled heating of the CTD cell at a rate of $25^{\circ} \mathrm{C}$ per minute represents an additional dimension in the dataset, constraining how easily individual compounds can be volatilized from the aerosols. Typical thermograms for chamber aerosol are given in Fig. 6 for different compounds, masses, and aerosol age. For better comparison of different concentration ranges the measured mixing ratios have been normalized for this analysis. The evaporation profile of each compound has been fitted according to

$Y\left(T \leq T_{a}\right)=0$, and $Y\left(T>T_{a}\right)=H \times\left(T-T_{a}\right)^{2} \times e^{-\left(\left(T-T_{a}\right) / W\right)}$,

where $Y$ is the signal in arbitrary units; $H, T_{a}$, and $W$ are free parameters (optimized by the non-linear least square method) and represent the height of the fit, the threshold temperature at which the compound is being evaporated, and the width of the evaporation profile, respectively.

It is noteworthy that the aerosol compounds evaporate at slightly higher temperatures with increasing aerosol age. The maximum of the fit shifts by a few degrees towards higher temperatures. The temperature at which the fitting function maximizes is shown in Fig. $7 \mathrm{~b}$ for all significant compounds that were detected in aerosols produced from $\alpha$ pinene ozonolysis. As a criterion of significance we used the condition that the maximum mixing ratio of the aerosol compound exceeds $30 \mathrm{nmol} / \mathrm{mol}$ in the $\mathrm{N}_{2}$ carrier gas. The maximum signal for all masses meeting this criterion (Fig. 7a) typically decreases by a factor of 3 from the first to the last measurement. The decrease is larger than the factor of 2 that is expected from dilution/deposition (compare with Fig. 5c), and reflects the fact that the thermogram profiles broaden with aerosol age. From Fig. 7b we learn that virtually all aerosol compounds are volatilized at higher temperatures as the aerosol becomes older. The lower volatility may partly be an effect of the lower aerosol burdens in the chamber as pointed out by Kostenidou et al. (2009). However, our finding holds for virtually all compounds and therefore it is unlikely that gas-particle partitioning is the only explanation. More research is needed to elucidate the underlying processes. 

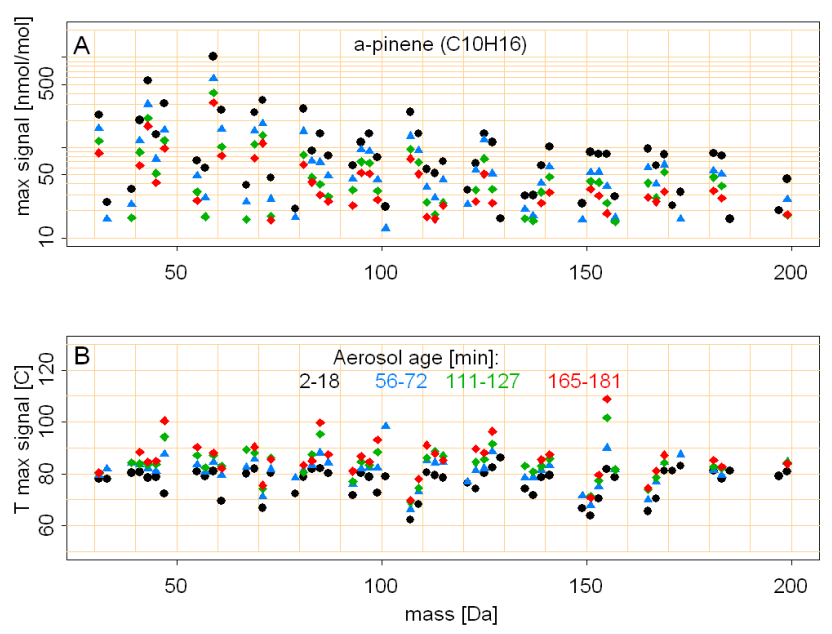

Fig. 7. Panel (a) shows the maximum signal of SOA-compounds during thermogram measurements. The SOA has been produced from ozone and $\alpha$-pinene. With increasing aerosol age the maximum signal decreases due to dilution/deposition (compare Fig. 5c), and due to the fact that the evaporation profiles broaden with aerosol age (compare Fig. 6). Panel (b) shows the temperature at which the maximum concentration is observed. Aged aerosol evaporates at higher temperatures.

\subsection{Ambient air measurements during the EUCAARI- IOP campaign}

Field measurements were carried out in May 2008 during the EUCAARI-IOP campaign at the Cabauw Experimental Site for Atmospheric Research (CESAR) site in the central Netherlands (http://www.knmi.nl/samenw/eucaari/). The TD-PTR-MS system was located inside the building and the aerosols were sampled from the roof at a height of $5 \mathrm{~m}$ above the ground through a $\sim 10 \mathrm{~m}$ long copper tube (ID=4 mm). During the field experiments the TD-PTR-MS instrument recorded full mass spectra in the mass range $20-219 \mathrm{Da}$ at a scanning speed of $0.2 \mathrm{~s}$ per mass unit, so a full mass scan was completed in 40 seconds.

Here we evaluate the period from 9-20 May, which can be sub-divided into 3 periods with different meteorological conditions: (i) 9-12 May was characterized by cloudless conditions with air masses flowing in from the east/southeast and carried pollution from Central/Eastern Europe (http: $/ /$ transport.nilu.no/flexpart-projects?stn $=\mathrm{CBW}$ ); (ii) between 13-16 May it was overcast, with significant rainfall on 16 May. Back trajectory calculations for this period show that the air masses were influenced by local emissions from the Netherlands and Northern Germany. The last period (iii) from 17-20 May showed a distinct marine influence from the North Sea and air masses had little recent contamination from continental sources.
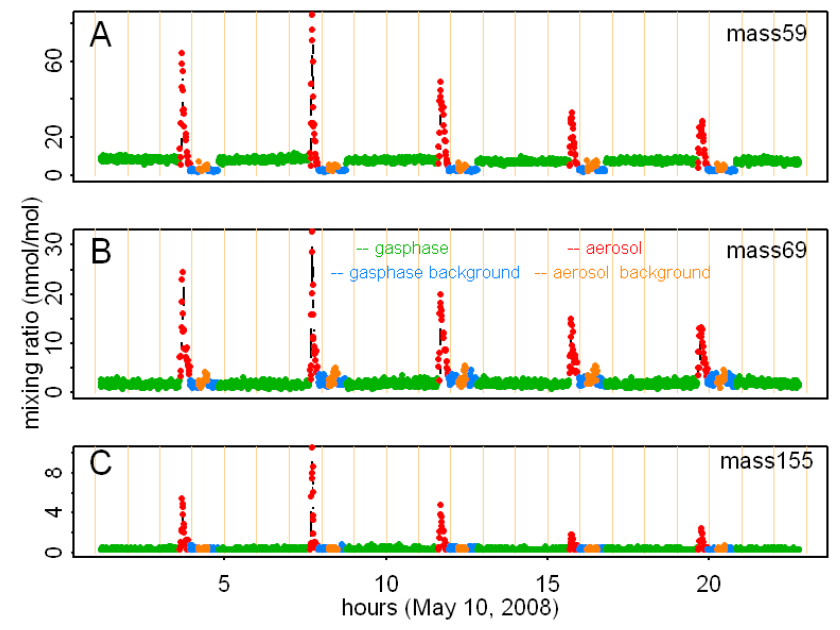

Fig. 8. Mixing ratios of example compounds measured during the EUCAARI-IOP campaign on 10 May 2008. The color code specifies what was measured. The highest and lowest aerosol measurement ( $\mathrm{m} 59$ at $\sim 7: 45$, and $\mathrm{m} 155$ at $\sim 15: 45$ ) correspond to an average aerosol concentration of 59 and $2.8 \mathrm{ng} / \mathrm{m}^{3}$, respectively, during the 172 minutes sampling period prior to the analysis.

Figure 8 shows mixing ratios of example ions that were detected at masses 59, 69, and 155 as measured on 10 May 2008. Whereas mass 59 most likely has the structure of protonated acetone $\left(\mathrm{C}_{3} \mathrm{H}_{7} \mathrm{O}^{+}\right)$, mass 69 and 155 cannot be attributed to a single molecular formula and different degrees of oxygenation have to be considered. Data in green represent periods of gas phase measurements during which the CTD cell was loaded with aerosols $\left(T_{\text {col }}=172 \mathrm{~min}\right)$. Data in red represent the period of aerosol analysis during which the CTD cell was heated to $350 \mathrm{C}$ at a rate of $25 \mathrm{~K} / \mathrm{min}$ $\left(t_{\text {meas }}=17 \mathrm{~min}\right)$. The cooling periods (blue data) were used to measure gas phase background mixing ratios by passing the sample air stream through a heated platinum catalyst $\left(T=350^{\circ} \mathrm{C}\right)$ that removed all organic compounds. The aerosol background was measured by analysing the unloaded CTD cell immediately after cooling (orange data in Fig. 8). A full cycle was completed in $4 \mathrm{~h}$. The signals of all aerosol measurements are clearly above the signals of the aerosol background measurements. The highest and lowest aerosol measurement in Fig. 8 (m59 at $~ 7: 45$, and $\mathrm{m} 155$ at $\sim 15: 45$ ) correspond to an average aerosol concentration of 59 and $2.8 \mathrm{ng} / \mathrm{m}^{3}$, respectively, during the $172 \mathrm{~min}$ sampling period prior to the analysis. The detection limit depends on the background signal and was calculated as 3 times the standard error of the aerosol background signal. The detection limit was below $0.2 \mathrm{ng} / \mathrm{m}^{3}$ for 67 and below $0.5 \mathrm{ng} / \mathrm{m}^{3}$ for 166 of the 200 monitored masses, respectively. This corresponds to $35-90 \mathrm{pg}$ of collected mass of an aerosol compound. On 10 May 2008, (i.e. the period shown in Fig. 8) the signals of 181 masses were above the detection limit and their total concentration summed up to $1900 \mathrm{ng} / \mathrm{m}^{3}$. 

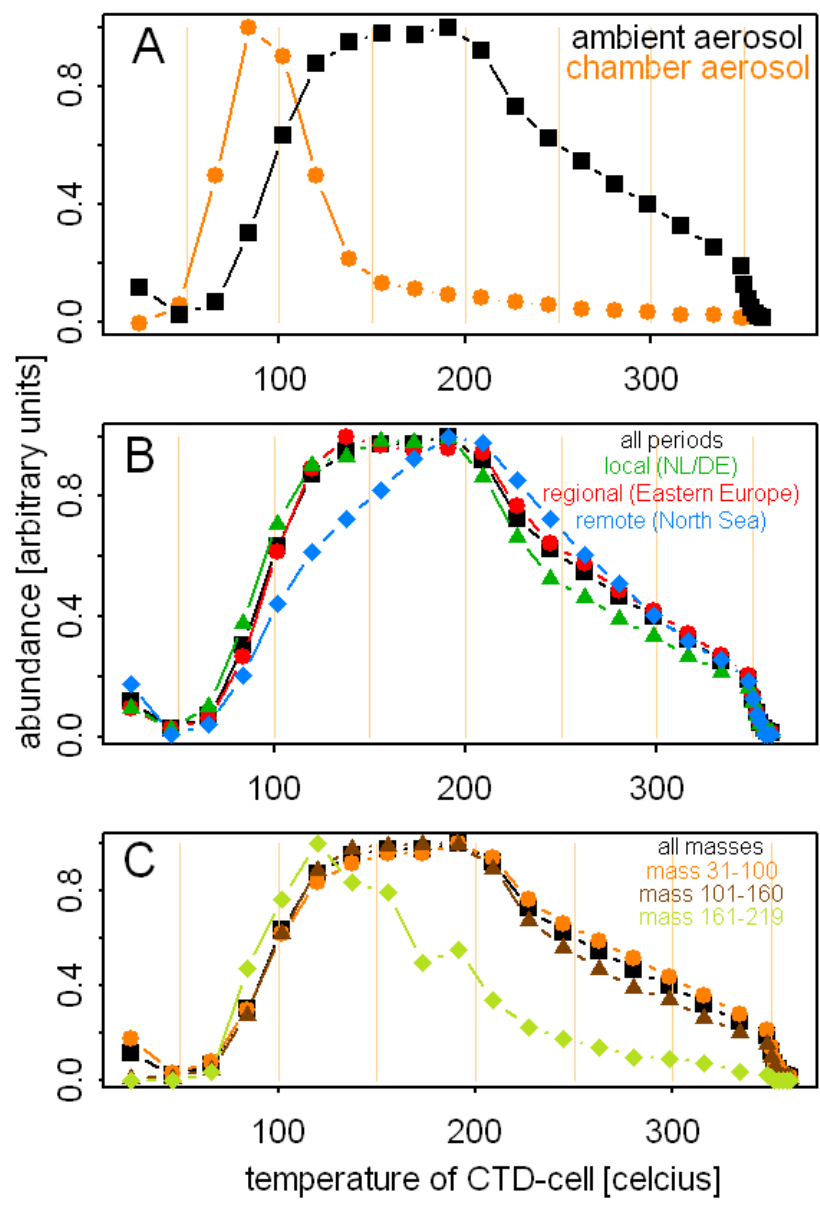

Fig. 9. (a) Averaged thermograms for all masses measured with a TD-PTR-MS for ambient aerosol (black) and chamber-generated aerosol (orange). Chamber aerosol is much more volatile. (b) Thermograms during the different meteorological conditions. Red circles: 9-12 May; green triangles: 13-26 May; blue diamonds: 1720 May. (c) Sub-division of the ambient aerosol thermograms into different mass ranges. See text for discussion.

Note that the background measurements during the field campaign had issues for both the gas phase and the aerosols. Many compounds showed unrealistically high concentrations during the gas phase background measurements due to a malfunctioning pressure controller that failed to compensate for the higher resistance of the inlet line when the air was streamed through the catalytic converter. The effect was a lower pressure in the drift tube and therefore the short-term contamination from the aerosol measurements contributed disproportionately to the background signal. Such an elevated background signal has been observed for many masses; an example can be seen in the second panel of Fig. 8 were the gas phase background of mass 69 is above the values of ambient air. The aerosol background measurements do not account for effects from semi-volatile gas phase compounds that may also stick to the walls of the CTD cell and may evaporate along with aerosol compounds during the analysis. Ideally the aerosol background is determined by loading the CTD cell through a filter that removes aerosols but not gas phase compounds before the background measurement.

\subsection{Comparison of thermograms obtained from cham- ber aerosol with thermograms obtained from ambi- ent aerosol}

Figure 9a juxtaposes the average thermograms (mass range was 30-220 Da) obtained from chamber SOA and from ambient samples. The first and most striking feature of these data is that the chamber SOA evaporates at much lower temperatures than ambient OA samples. The lab SOA does not look like ambient OA. This finding applies to SOA generated in the lab from reactions of ozone and $\alpha$-pinene, limonene, and $\beta$-caryophyllene, and likewise to ambient OA obtained under clear and rainy "continental" and clear "marine" conditions.

Figure $9 \mathrm{~b}$ shows that the thermograms of ambient aerosol are different for the three source regions. The photochemically younger aerosol from the 13-16 May period is slightly more volatile than the more aged aerosol from the 9-12 May period. Both these periods are significantly more volatile than the (presumably) very aged aerosol sampled during the period of marine influence (17-20 May).

Average thermograms of different mass ranges from ambient data are shown in Fig. 9c. As compared to electronionization typically employed in aerosol mass spectrometry (AMS), our TD-PTR-MS data are substantially less fragmented, with numerous large peaks in the 100-220 Da range. Thus we can potentially gain some insight into the molecular weight of the compounds evolving from the thermal desorption sampler. Nonetheless, the TD-PTR-MS data also contain a significant mass fraction in relatively light fragments, below $100 \mathrm{Da}$. Molecules of this low molecular weight are highly unlikely to be found in the condensed phase as monomers (Pankow and Asher, 2008), and so it is very likely that these are fragments produced either after proton transfer or during thermal desorption. Consistent with this hypothesis, the lightest fractions in Fig. 9c evolve at the highest temperatures, suggesting that these are indeed associated with the least volatile organics in the sample. An interesting parallel is found in AMS thermodenuder data, where the OOA factors are dominated by low molecular weight fragments but also are much less volatile than the more reduced primary aerosol (HOA), which in turn has a characteristic "picket fence" spectrum extending out to relatively high $\mathrm{m} / \mathrm{z}$ (Huffman et al., 2009; Zhang et al., 2007).

The comparison of thermograms clearly shows that conventional chamber SOA experiments do not produce organic aerosol that looks like ambient OA samples from the perspective of the TD-PTR-MS system. Even the most volatile molecular weight fraction (161-219 Da) from the ambient data is much less volatile than the chamber aerosol. The 
issue is not that chamber experiments are wrong, but rather that they may be incomplete. From precursor emission to deposition, organic aerosols are believed to reside in the atmosphere for roughly one week if they remain in the boundary layer, or many weeks if they escape to the free troposphere (Williams et al., 2002). However, chamber experiments typically only span a few hours. Gas-phase oxidation (by $\mathrm{OH}$ radicals) thus appears to be a part of the ambient aging process. Several other plausible mechanisms have been proposed (e.g. Kostenidou et al., 2009), however, and in all likelihood several do play a role in the real world. To test these different mechanisms, the less fragmented spectra obtained in the TD-PTR-MS may prove vital. The new development of a high mass resolution TD-PTR-MS (equipped with a time-of-flight mass spectrometer) has a high potential to provide insight into these mechanisms because the high mass resolution allows an accurate measurement of the degree of oxygenation of the organic aerosol.

\section{Conclusions}

We successfully developed a new analytical approach for quantitative analysis of organic aerosol. The TD-PTRMS instrument directly quantifies a fraction of $55-80 \%$ of laboratory-generated organic aerosol. Controlled thermaldesorption from the collection cell gives additional information on the volatility of aerosol compounds and a comparison of thermograms from chamber aerosol and ambient aerosol revealed large differences between these types of particles. Ageing processes have been observed in both the chamber and ambient aerosol. The combination of reasonable temporal resolution, low detection limit, and good physicochemical characterization of organic aerosol indicate the high potential of this technique for future applications which goes beyond of what is presented here. Unlike other aerosol instruments our approach is sensitive also to intermediate volatility and semi-volatile compounds and it provides the option for combined in situ gas phase and aerosol measurements of such compounds. Better quantification of the degree of oxygenation of organic aerosols and a better elucidation of corresponding chemical oxidation processes are other promising areas of application for this instrument.

Acknowledgements. We thank the colleagues from KNMI and the Cabauw team for support during the field measurements. Richard Winterhalter is gratefully acknowledged for maintaining the SMPS system. This work was partly funded by The Netherlands Organization for Scientific Research (NWO) under the ALW-Middelgroot program (Grant 834.08.002).

Edited by: V. F. McNeill

\section{References}

Aiken, A. C., Decarlo, P. F., Kroll, J. H., Worsnop, D. R., Huffman, J. A., Docherty, K. S., Ulbrich, I. M., Mohr, C., Kimmel, J. R., Sueper, D., Sun, Y., Zhang, Q., Trimborn, A., Northway, M., Ziemann, P. J., Canagaratna, M. R., Onasch, T. B., Alfarra, M. R., Prevot, A. S. H., Dommen, J., Duplissy, J., Metzger, A., Baltensperger, U., and Jimenez, J. L.: O/C and OM/OC ratios of primary, secondary, and ambient organic aerosols with high-resolution time-of-flight aerosol mass spectrometry, Environ. Sci. Technol., 42, 4478-4485, 2008.

Cappa, C. D., Lovejoy, E. R., and Ravishankara, A. R.: Evidence for liquid-like and nonideal behavior of a mixture of organic aerosol components, Proceedings of the National Academy of Sciences of the United States of America, 105, 18687-18691, 2008.

DeCarlo, P. F., Kimmel, J. R., Trimborn, A., Northway, M. J., Jayne, J. T., Aiken, A. C., Gonin, M., Fuhrer, K., Horvath, T., Docherty, K. S., Worsnop, D. R., and Jimenez, J. L.: Field-deployable, high-resolution, time-of-flight aerosol mass spectrometer, Anal. Chem., 78, 8281-8289, 2006.

Demarcke, M., Amelynck, C., Schoon, N., Dhooghe, F., Van Langenhove, H., and Dewulf, J.: Laboratory studies in support of the detection of sesquiterpenes by proton-transfer-reaction-massspectrometry, Int. J. Mass Spectrom., 279, 156-162, 2009.

Donahue, N. M., Robinson, A. L., Stanier, C. O., and Pandis, S. N.: Coupled partitioning, dilution, and chemical aging of semivolatile organics, Environ. Sci. Technol., 40, 2635-2643, 2006.

Ervens, B., Carlton, A. G., Turpin, B. J., Altieri, K. E., Kreidenweis, S. M., and Feingold, G.: Secondary organic aerosol yields from cloud-processing of isoprene oxidation products, Geophys. Res. Lett., 35, L02816, doi:10.1029/2007GL031828, 2008.

Goldstein, A. H. and Galbally, I. E.: Known and unexplored organic constituents in the earth's atmosphere, Environ. Sci. Technol., 41, 1514-1521, 2007.

Grieshop, A. P., Logue, J. M., Donahue, N. M., and Robinson, A. L.: Laboratory investigation of photochemical oxidation of organic aerosol from wood fires 1: measurement and simulation of organic aerosol evolution, Atmos. Chem. Phys., 9, 1263-1277, 2009 ,

http://www.atmos-chem-phys.net/9/1263/2009/.

Hallquist, M., Wenger, J. C., Baltensperger, U., Rudich, Y., Simpson, D., Claeys, M., Dommen, J., Donahue, N. M., George, C., Goldstein, A. H., Hamilton, J. F., Herrmann, H., Hoffmann, T., Iinuma, Y., Jang, M., Jenkin, M. E., Jimenez, J. L., Kiendler-Scharr, A., Maenhaut, W., McFiggans, G., Mentel, Th. F., Monod, A., Prévôt, A. S. H., Seinfeld, J. H., Surratt, J. D., Szmigielski, R., and Wildt, J.: The formation, properties and impact of secondary organic aerosol: current and emerging issues, Atmos. Chem. Phys., 9, 5155-5236, 2009,

http://www.atmos-chem-phys.net/9/5155/2009/.

Heald, C. L., Goldstein, A. H., Allan, J. D., Aiken, A. C., Apel, E., Atlas, E. L., Baker, A. K., Bates, T. S., Beyersdorf, A. J., Blake, D. R., Campos, T., Coe, H., Crounse, J. D., DeCarlo, P. F., de Gouw, J. A., Dunlea, E. J., Flocke, F. M., Fried, A., Goldan, P., Griffin, R. J., Herndon, S. C., Holloway, J. S., Holzinger, R., Jimenez, J. L., Junkermann, W., Kuster, W. C., Lewis, A. C., Meinardi, S., Millet, D. B., Onasch, T., Polidori, A., Quinn, P. K., Riemer, D. D., Roberts, J. M., Salcedo, D., Sive, B., Swanson, A. L., Talbot, R., Warneke, C., Weber, R. J., Weib- 
ring, P., Wennberg, P. O., Worsnop, D. R., Wittig, A. E., Zhang, R., Zheng, J., and Zheng, W.: Total observed organic carbon (TOOC) in the atmosphere: a synthesis of North American observations, Atmos. Chem. Phys., 8, 2007-2025, 2008,

http://www.atmos-chem-phys.net/8/2007/2008/.

Hearn, J. D. and Smith, G. D.: A chemical ionization mass spectrometry method for the online analysis of organic aerosols, Anal. Chem., 76, 2820-2826, 2004.

Hellen, H., Dommen, J., Metzger, A., Gascho, A., Duplissy, J., Tritscher, T., Prevot, A. S. H., and Baltensperger, U.: Using proton transfer reaction mass spectrometry for online analysis of secondary organic aerosols, Environ. Sci. Technol., 42, 73477353, 2008.

Hildebrandt, L., Donahue, N. M., and Pandis, S. N.: High formation of secondary organic aerosol from the photo-oxidation of toluene, Atmos. Chem. Phys., 9, 2973-2986, 2009,

http://www.atmos-chem-phys.net/9/2973/2009/.

Holzinger, R., Millet, D. B., Williams, B., Lee, A., Kreisberg, N., Hering, S. V., Jimenez, J., Allan, J. D., Worsnop, D. R., and Goldstein, A. H.: Emission, oxidation, and secondary organic aerosol formation of volatile organic compounds as observed at Chebogue Point, Nova Scotia, J. Geophys. Res.-Atmos., 112, D10S24, doi:10.1029/2006JD007599, 2007.

Huffman, J. A., Docherty, K. S., Aiken, A. C., Cubison, M. J., Ulbrich, I. M., DeCarlo, P. F., Sueper, D., Jayne, J. T., Worsnop, D. R., Ziemann, P. J., and Jimenez, J. L.: Chemically-resolved aerosol volatility measurements from two megacity field studies, Atmos. Chem. Phys., 9, 7161-7182, 2009,

http://www.atmos-chem-phys.net/9/7161/2009/.

Jimenez, J. L., Canagaratna, M. R., Donahue, N. M., Prevot, A. S. H., Zhang, Q., Kroll, J. H., DeCarlo, P. F., Allan, J. D., Coe, H., Ng, N. L., Aiken, A. C., Docherty, K. S., Ulbrich, I. M., Grieshop, A. P., Robinson, A. L., Duplissy, J., Smith, J. D., Wilson, K. R., Lanz, V. A., Hueglin, C., Sun, Y. L., Tian, J., Laaksonen, A., Raatikainen, T., Rautiainen, J., Vaattovaara, P., Ehn, M., Kulmala, M., Tomlinson, J. M., Collins, D. R., Cubison, M. J., Dunlea, E. J., Huffman, J. A., Onasch, T. B., Alfarra, M. R., Williams, P. I., Bower, K., Kondo, Y., Schneider, J., Drewnick, F., Borrmann, S., Weimer, S., Demerjian, K., Salcedo, D., Cottrell, L., Griffin, R., Takami, A., Miyoshi, T., Hatakeyama, S., Shimono, A., Sun, J. Y., Zhang, Y. M., Dzepina, K., Kimmel, J. R., Sueper, D., Jayne, J. T., Herndon, S. C., Trimborn, A. M., Williams, L. R., Wood, E. C., Middlebrook, A. M., Kolb, C. E., Baltensperger, U., and Worsnop, D. R.: Evolution of Organic Aerosols in the Atmosphere, Science, 326, 1525-1529, 2009.

Kanakidou, M., Seinfeld, J. H., Pandis, S. N., Barnes, I., Dentener, F. J., Facchini, M. C., Van Dingenen, R., Ervens, B., Nenes, A., Nielsen, C. J., Swietlicki, E., Putaud, J. P., Balkanski, Y., Fuzzi, S., Horth, J., Moortgat, G. K., Winterhalter, R., Myhre, C. E. L., Tsigaridis, K., Vignati, E., Stephanou, E. G., and Wilson, J.: Organic aerosol and global climate modelling: a review, Atmos. Chem. Phys., 5, 1053-1123, 2005,

http://www.atmos-chem-phys.net/5/1053/2005/.

Kostenidou, E., Lee, B. H., Engelhart, G. J., Pierce, J. R., and Pandis, S. N.: Mass Spectra Deconvolution of Low, Medium, and High Volatility Biogenic Secondary Organic Aerosol, Environ. Sci. Technol., 43, 4884-4889, 2009.

Kroll, J. H., Ng, N. L., Murphy, S. M., Flagan, R. C., and Seinfeld, J. H.: Secondary organic aerosol formation from isoprene photooxidation, Environ. Sci. Technol., 40, 1869-1877, 2006.

Kroll, J. H., Ng, N. L., Murphy, S. M., Varutbangkul, V., Flagan, R. C., and Seinfeld, J. H.: Chamber studies of secondary organic aerosol growth by reactive uptake of simple carbonyl compounds, J. Geophys. Res.-Atmos., 110, D23207, doi:10.1029/2005JD006004, 2005.

Lanz, V. A., Alfarra, M. R., Baltensperger, U., Buchmann, B., Hueglin, C., Szidat, S., Wehrli, M. N., Wacker, L., Weimer, S., Caseiro, A., Puxbaum, H., and Prevot, A. S. H.: Source attribution of submicron organic aerosols during wintertime inversions by advanced factor analysis of aerosol mass spectra, Environ. Sci. Technol., 42, 214-220, 2008.

Lindinger, W., Hansel, A., and Jordan, A.: On-line monitoring of volatile organic compounds at pptv levels by means of protontransfer-reaction mass spectrometry (PTR-MS) - Medical applications, food control and environmental research, Int. J. Mass Spectrom., 173, 191-241, 1998.

Ng, N. L., Kroll, J. H., Chan, A. W. H., Chhabra, P. S., Flagan, R. C., and Seinfeld, J. H.: Secondary organic aerosol formation from m-xylene, toluene, and benzene, Atmos. Chem. Phys., 7, 3909-3922, 2007,

http://www.atmos-chem-phys.net/7/3909/2007/.

Pankow, J. F. and Asher, W. E.: SIMPOL.1: a simple group contribution method for predicting vapor pressures and enthalpies of vaporization of multifunctional organic compounds, Atmos. Chem. Phys., 8, 2773-2796, 2008,

http://www.atmos-chem-phys.net/8/2773/2008/.

Paulot, F., Crounse, J.D., Kjaergaard, H.G. Kürten, A., St. Clair, J.M., Seinfeld, J.H., and Wennberg, P.O.: Unexpected epoxide formation in the gas-phase photooxidation of isoprene, Science, 325, 730-733, 2009.

Robinson, A. L., Donahue, N. M., Shrivastava, M. K., Weitkamp, E. A., Sage, A. M., Grieshop, A. P., Lane, T. E., Pierce, J. R., and Pandis, S. N.: Rethinking organic aerosols: Semivolatile emissions and photochemical aging, Science, 315, 1259-1262, 2007.

Thornberry, T., Murphy, D. M., Thomson, D. S., de Gouw, J., Warneke, C., Bates, T. S., Quinn, P. K., and Coffman, D.: Measurement of Aerosol Organic Compounds Using a Novel Collection/Thermal-Desorption PTR-ITMS Instrument, Aerosol Sci. Technol., 43, 486-501, 2009.

Tobias, H. J. and Ziemann, P. J.: Thermal desorption mass spectrometric analysis of organic aerosol formed from reactions of 1-tetradecene and O-3 in the presence of alcohols and carboxylic acids, Environ. Sci. Technol., 34, 2105-2115, 2000.

Volkamer, R., Jimenez, J. L., San Martini, F., Dzepina, K., Zhang, Q., Salcedo, D., Molina, L. T., Worsnop, D. R., and Molina, M. J.: Secondary organic aerosol formation from anthropogenic air pollution: Rapid and higher than expected, Geophys. Res. Lett., 33, L17811, doi:10.1029/2006GL026899, 2006.

Volkamer, R., Martini, F. S., Molina, L. T., Salcedo, D., Jimenez, J. L., and Molina, M. J.: A missing sink for gas-phase glyoxal in Mexico City: Formation of secondary organic aerosol, Geophys. Res. Lett., 34, L19807, doi:10.1029/2007GL030752, 2007.

Williams, B. J., Goldstein, A. H., Kreisberg, N. M., and Hering, S. V.: An in-situ instrument for speciated organic composition of atmospheric aerosols: Thermal Desorption Aerosol GC/MS-FID (TAG), Aerosol Sci. Technol., 40, 627-638, 2006.

Williams, J., de Reus, M., Krejci, R., Fischer, H., and Ström, J.: Application of the variability-size relationship to atmospheric 
aerosol studies: estimating aerosol lifetimes and ages, Atmos. Chem. Phys., 2, 133-145, 2002,

http://www.atmos-chem-phys.net/2/133/2002/.

Zhang, Q., Jimenez, J. L., Canagaratna, M. R., Allan, J. D., Coe, H., Ulbrich, I., Alfarra, M. R., Takami, A., Middlebrook, A. M., Sun, Y. L., Dzepina, K., Dunlea, E., Docherty, K., DeCarlo, P. F., Salcedo, D., Onasch, T., Jayne, J. T., Miyoshi, T., Shimono, A., Hatakeyama, S., Takegawa, N., Kondo, Y., Schneider, J., Drewnick, F., Borrmann, S., Weimer, S., De- merjian, K., Williams, P., Bower, K., Bahreini, R., Cottrell, L., Griffin, R. J., Rautiainen, J., Sun, J. Y., Zhang, Y. M., and Worsnop, D. R.: Ubiquity and dominance of oxygenated species in organic aerosols in anthropogenically-influenced Northern Hemisphere midlatitudes, Geophys. Res. Lett., 34, L13801, doi:10.1029/2007GL029979, 2007.

Zhao, J. and Zhang, R. Y.: Proton transfer reaction rate constants between hydronium ion $(\mathrm{H} 3 \mathrm{O}(+))$ and volatile organic compounds, Atmos. Environ., 38, 2177-2185, 2004. 